\title{
Pathogenetical Characterization of MHV-76: a Spontaneous 9.5-Kilobase-Deletion Mutant of Murine Lymphotropic Gammaherpesvirus 68
}

\author{
A. CHALUPKOVÁ ${ }^{1}$, M. HRICOVÁ ${ }^{1}$, Z. HRABOVSKÁ ${ }^{1}$, J. MISTRÍKOVÁ ${ }^{1,2}$ \\ ${ }^{1}$ Department of Microbiology and Virology, Faculty of Natural Sciences, Comenius University, Bratislava, \\ Slovak Republic \\ ${ }^{2}$ Institute of Virology, Slovak Academy of Sciences, Bratislava, Slovak Republic
}

Received September 26, 2007

Accepted February 14, 2008

\begin{abstract}
Chalupková A., M. Hricová, Z. Hrabovská, J. Mistríková: Pathogenetical Characterization of MHV-76: a Spontaneous 9.5-Kilobase-Deletion Mutant of Murine Lymphotropic Gammaherpesvirus 68. Acta Vet. Brno 2008, 77: 231-237.

Murid gammaherpesvirus 4 (MuHV-4) provides a small animal model for the study of animal gammaherpesviruses. MHV-76 is a spontaneous deletion mutant as compared to the prototype strain of MuHV-4 (MHV-68). The MHV-76 genome lacks at least 12 ORFs at the 5'-end including the M1, M2, M3 and M4 genes and the eight viral t-RNA-like genes. During 27 months of experimental infection of BALB/c mice we followed their pathogenesis, immunology and oncogenic properties. After intranasal infection with MHV-76, the infectious virus was detected in the blood, thymus, lungs, heart, liver, spleen, bone marrow, peritoneal macrophages, lymph nodes, kidneys, mammary glands, brain and small intestine. The acute phase of infection was attenuated, but the chronic phase of infection was accompanied with long persistence of virus not only in the lymphatic, but in the neural and glandular tissue, as well. In comparison with the prototype strain, splenomegaly and lymphocytosis was very low. Surprisingly, during 27 months the BALB/c mice infected with MHV-76 did not develop lymphoproliferative disorders like infectious mononucleosis, leukaemia or lymphomas. We hypothesize that the M4 gene, present in all oncogenic MHV isolates, might be related (directly or indirectly) to their transforming properties.
\end{abstract}

Mouse herpesvirus 76, deletion mutant, pathogenesis, oncogenesis, M4 gene, acute infection, chronic infection, atypical lymphocytes, lymphoproliferation

The interest in biology of gammaherpesviruses stems largely from their association with a variety of malignancies. The Human Epstein-Barr virus (EBV) and animal Herpesvirus Saimiri (HVS) are associated with lymphoproliferative disorders. MHV-68 along with isolates $60,72,76,78$ and Šmava belongs to the MuHV-4 species, a member of Rhadinovirus genus of the subfamily Gammaherpesvirinae (Fauquet et al. 2005).

MHV-68 represents a small animal model for the study of gammaherpesvirus pathogenesis. MHV-68 established a latent infection in B-lymphocytes, following an acute respiratory infection. In late stages of a long-term infection, $10 \%$ of mice developed a lymphoproliferative disease. A high proportion of these mice (50\%) displayed high-grade lymphomas (Sunil-Chandra et al. 1994; Mistríková et al. 1996). MHV-60, MHV-68, MHV-72, MHV-78 and MHV-Šumava have an oncogenic potential including tumours in $22 \%, 9 \%, 11 \%, 7 \%$ and $14.5 \%$, respectively (Pappová et al. 2004; Sunil-Chandra et al. 1994; Mistríková et al. 1996, 2002; Mrmusová-Šupolíková et al. 2003). Our research was focused on MHV-76, another isolate of MHV-68 (Blaškovič et al. 1980), which was isolated at the same time as MHV-68, but from a different murid species - a yellow-necked wood mouse Apodemus flavicollis. MHV-76 is supposed to be identical to MHV-68, except for genes M1, M2, M3 and M4 as well as eight vt-RNAs on the left end of the genome. On the basis of growth characteristics in cell culture and the cytopathic effect, MHV-76 was originally described as an alphaherpesvirus (Svobodová et al. 1982), Reichel et al. (1991)

Address for correspondence:

Doc. RNDr. Jela Mistríková, CSc.

Department of Microbiology and Virology

Faculty of Sciences, Comenius University

Mlynská dolina B2, 84215 Bratislava
Phone + 421254773172

$\mathrm{Fax}+421260296436$

E-mail virumis@savba.sk,mistrikova@fns.uniba.sk

http://www.vfu.cz/acta-vet/actavet.htm 
found resemblance in the polypeptide profiles of MHV-76 and Herpes simplex in the rabbit embryo fibroblast cell, but it could be accidental due to glycolysation and phosphorylation of particular polypeptides. However, genomic analysis of MHV-68 (Efstathiou et al. 1990) classified it as gammaherpesvirus. Hamelin and Lussier (1992) used restriction endonuclease, dot-blot hybridization and cross-hybridization to show a high level of DNA homology between MHV-76 and rat cytomegalovirus (a betaherpesvirus). They hypothesized MHV-76 is a possible member of all 3 subfamilies. Macrae et al. (2001) on the basis of molecular analysis of MHV-76 concluded that MHV-76 has a genome structure nearly identical to that of MHV-68, except a $9.5 \mathrm{kbp}$ deletion that contains the M1, M2, M3 and M4 and eight viral t-RNA-like genes. On the basis of MHV-76 analysis authors reported that this locus is important for acute pathogenesis, including acute replication and establishment of MHV-68 latency in the spleen following intranasal infection. Since MHV-76 is supposed to be identical to oncogenic MHV-68, except for deletion genes, we wanted to analyze how these deletions influence the pathogenesis during long-term infection and the oncogenic potential.

\section{Materials and Methods}

Virus

The MHV-76 stock was prepared by infection of VERO cells and harvesting at 72 or $96 \mathrm{~h}$ post infection (p.i.). Cells were disrupted and the virus was released by homogenization and sonication. The supernatant was stored at $-70{ }^{\circ} \mathrm{C}$ until use. Infectious virus was assayed by plaque titration in VERO cells.

\section{Animals}

BALB/c mice coming from the Faculty of Veterinary Medicine, Brno, Czech Republic were kept at the Institute of Virology, Slovak Academy of Sciences, Bratislava, under standard housing conditions. Eighty of 100 female 4 - 6-week-old mice were inoculated intranasally (i.n.) with $2.10^{5}$ PFU $(20 \mu \mathrm{l})$ of the virus per mouse under light anaesthesia with ether. Twenty of 100 non-infected 4 - 6-week-old mice served as controls. All procedures using animals were performed in accordance with the European Convention for the Protection of Vertebrate Animals Used for Experimental and Other Scientific Purposes from 1986.

Experiments with mice

Mice were killed at different times during acute infection $(3,5,7,12,14,20,25,28$ d.p.i.) and chronic infection $(1,3,5,7,9,11,13,15,17,24,27$ months p.i.) by cervical dislocation. The blood, thymus, lungs, heart, liver, spleen, bone marrow, peritoneal macrophages, lymph nodes, kidneys, mammary glands, brain, and small intestine were removed and used for preparation of cell suspensions for detection of virus and viral antigen by immunofluorescence test. Specimens for detection of the virus were collected and stored at $-70{ }^{\circ} \mathrm{C}$ until virus titration. Blood samples were taken from sinus orbitalis at different times during acute infection $(3,5,7,12,14$, 20, 25, 28 d.p.i.) and chronic infection (1, 3, 5, 7, 9, 11, 13, 15, 17, 24, 27 months p.i.) instantly with heparin (final concentration of 2 - $4 \mathrm{U} / \mathrm{ml}$ to prevent blood clotting).

Staining of blood elements

Blood smears were made immediately after blood collection. After fixation by air drying they were stained by May-Grünwald solution for $10 \mathrm{~min}$ and then by Giemsa-Romanowski solution for $15 \mathrm{~min}$. Stain solution was removed by rinsing with tap water and smears were examined by microscopy with immersion oil. Differential white blood cell count was done by calculation of percentage of each kind of white blood cells.

The amount of $25 \mathrm{ml}$ of unclotted blood was added to $475 \mu \mathrm{l}$ of Turk solution for $10 \mathrm{~min}$ and then the number of leukocytes was determined.

Titration of virus

Titration of infectious virus was done in VERO cells. Frozen homogenates of organs were thawed and clarified by low-speed centrifugation and then diluted 10 -fold serially up to $10^{-6}$ in Dulbecco's Modified Eagle's Medium supplemented with $3 \%$ of heat-inactivated bovine serum, glutamine (300 mg/l) and gentamicin $(80 \mathrm{mg} / \mathrm{l})$. Each dilution $(0.1 \mathrm{ml}$ per culture vessel) was used for infecting the VERO cell monolayer. After $3-7$ days of incubation at $37{ }^{\circ} \mathrm{C}$ in $5 \% \mathrm{CO}_{2}$ the monolayer was fixed and stained and the cytopathic effect (CPE) was evaluated.

Immunofluorescence (IF) test

The presence of virus antigen in cells from organs of infected mice was determined by indirect IF test and the percentage of positive cells was calculated. Suspension of cells $(100 \mu 1)$ obtained from organ tissues of infected mice was washed with PBS prior to staining with a monoclonal antibody (Mab) against MHV (dilution $1: 100-1: 500)$ for $45 \mathrm{~min}$ at $37^{\circ} \mathrm{C}$. The monoclonal antibody was prepared in our laboratory (Matušková 
et al. 2003). After three washes in PBS the samples were stained with a goat anti-mouse IgG $(\mathrm{H}+\mathrm{L})$ conjugated with rhodamine (Immunotech, Slovak Republic) and incubated at $37^{\circ} \mathrm{C}$ for $45 \mathrm{~min}$. Followed by washing with PBS three times, the cells were mounted in mounting solution and examined under fluorescence.

Neutralisation assay

Sera obtained from infected mice were heat-inactivated $\left(56^{\circ} \mathrm{C}\right.$ for $\left.30 \mathrm{~min}\right)$ and diluted in Dulbecco's Modified Eagle's Medium (supplemented with $2 \%$ of heat-inactivated bovine serum, glutamine and gentamicin) with an initial serum dilution of $1: 2$. The tissue culture infectious dose $\left(\mathrm{TCID}_{50}\right)$ of the virus stocks was determined, diluted sera and virus samples were mixed $\left(100 \mu \mathrm{l}\right.$ of each), and the mixture was incubated at $37{ }^{\circ} \mathrm{C}$ for $1 \mathrm{~h}$. The virus-serum mixtures were then inoculated on the VERO cell monolayer in a 96-well dish and monitored for the development of the cytopathic effect. The neutralising titre of a particular serum was defined as the reciprocal of $50 \%$ of the highest dilution that resulted in no observable cytopathic effect.

\section{Results}

One hundred BALB/c mice were used for the experiment. Eighty of 100 were infected with MHV-76 and 20/100 served as non-infected control. Infected and non-infected groups of mice were observed for 27 months. MHV-76 in comparison with the prototype strain MHV-68 did not show apparent symptoms of illness. Thirteen specimens from different organs were observed for the presence of virus: blood, thymus, lungs, heart, liver, spleen, bone marrow, peritoneal macrophages, lymph nodes, kidneys, mammary glands, brain, and small intestine of 4 - 6 week-old BALB/c mice infected intranasally with $2.10^{5}$ PFU of MHV-76 per mouse. Four of the infected mice and one non-infected mouse were sacrificed on days $3,5,7,12,14,20,25,28$ d.p.i., during acute infection and in month 1, 3, 5, 7, 9, 11, $13,15,17,24,27$ during chronic infection. Blood samples were taken at certain intervals chosen on the basis of our previous experiments with MHV-72 (Mistríková et al. 1994), MHV-Šumava (Mistríková et al. 2002), MHV-78 (Mrmusová-Šupolíková et al. 2003) and MHV-60 (Pappová et al. 2004). Results of our experiments are demonstrated in Table 1 (acute infection) and Table 2 (chronic infection). Infectious virus and virus antigen was detected by cocultivation with permissive VERO cells and indirect immunofluorescence using monoclonal antibodies prepared against MHV. During the acute phase of infection

Table 1. Detection of infectious virus and viral antigen in 4-6-week-old BALB/c mice infected with MHV-76 during acute phase of infection

\begin{tabular}{|l|c|c|c|c|c|c|c|c|c|}
\hline Organ & $3 \mathrm{dpi}$ & $5 \mathrm{dpi}$ & $7 \mathrm{dpi}$ & $12 \mathrm{dpi}$ & $14 \mathrm{dpi}$ & $17 \mathrm{dpi}$ & $20 \mathrm{dpi}$ & $25 \mathrm{dpi}$ & $28 \mathrm{dpi}$ \\
\hline Blood & - & + & + & - & - & + & + & + & + \\
\hline Thymus & + & + & + & + & + & - & - & - & + \\
\hline Lungs & + & + & + & - & + & + & + & - & + \\
\hline Heart & - & + & + & - & + & + & + & + & + \\
\hline Liver & + & + & + & + & + & + & + & + & + \\
\hline Spleen & - & - & + & + & + & + & - & + & + \\
\hline Bone marrow & - & + & - & - & + & + & + & - & - \\
\hline $\begin{array}{l}\text { Peritoneal } \\
\text { macrophages }\end{array}$ & - & - & - & - & + & + & + & + & + \\
\hline Lymph nodes & - & + & + & + & + & + & + & + & + \\
\hline Kidney & - & + & + & + & + & + & + & + & - \\
\hline $\begin{array}{l}\text { Mammary } \\
\text { glands }\end{array}$ & $\mathrm{ND}$ & $\mathrm{ND}$ & $\mathrm{ND}$ & $\mathrm{ND}$ & $\mathrm{ND}$ & $\mathrm{ND}$ & $\mathrm{ND}$ & $\mathrm{ND}$ & ND \\
\hline Brain & - & - & + & + & - & + & + & - & + \\
\hline $\begin{array}{l}\text { Small } \\
\text { intestine }\end{array}$ & - & - & - & - & - & - & + & - & + \\
\hline
\end{tabular}

Mice were infected i.n. with $2.10^{5}$ PFU of MHV-76 per mouse. Titre of virus evaluated as $(-)$ negative, $(+)$ positive specimens only in concentrated suspension, $(++)$ positive specimens in dilution $10^{-1} \cdot( \pm \pm)$ positivity of speciment confirmed with immunofluorescent method - IF , ND = not done 
Table 2. Detection of infectious virus and viral antigen in 4-6-week-old BALB/c mice infected with MHV-76 during chronic phase of infection

\begin{tabular}{|l|c|c|c|c|c|c|c|c|c|c|c|}
\hline Organ & $1 \mathrm{mpi}$ & $3 \mathrm{mpi}$ & $5 \mathrm{mpi}$ & $7 \mathrm{mpi}$ & $9 \mathrm{mpi}$ & $11 \mathrm{mpi}$ & $13 \mathrm{mpi}$ & $15 \mathrm{mpi}$ & $17 \mathrm{mpi}$ & $24 \mathrm{mpi}$ & $27 \mathrm{mpi}$ \\
\hline Blood & ++ & - & +++ & - & - & ++ & + & - & - & - & + \\
\hline Thymus & - & + & + & ++ & - & + & + & + & + & ++ & + \\
\hline Lungs & + & - & ++ & - & ++ & ++ & + & - & - & - & - \\
\hline Heart & + & - & ++ & + & - & ++ & - & - & - & ++ & ++ \\
\hline Liver & - & - & +++ & +++ & ++ & \pm+1 & ++ & +++ & ++ & +++ & \pm \pm+ \\
\hline Spleen & + & & + & +++ & +++ & \pm+ & ++ & ++ & ++ & \pm \pm \pm & - \\
\hline Bone marrow & + & + & ++ & + & ++ & + & ++ & + & - & ++ & + \\
\hline $\begin{array}{l}\text { Peritoneal } \\
\text { macrophages }\end{array}$ & + & + & + & ++ & + & + & + & + & - & + & - \\
\hline Lymph nodes & + & + & ++ & + & + & + & ++ & ++ & + & + & - \\
\hline Kidney & + & + & ++ & + & ++ & ++ & ++ & ++ & + & ++ & ++ \\
\hline $\begin{array}{l}\text { Mammary } \\
\text { glands }\end{array}$ & - & + & - & + & + & ++ & + & +++ & + & - & - \\
\hline Brain & + & + & - & +++ & + & + & + & ++ & - & - & \pm \pm \\
\hline $\begin{array}{l}\text { Small } \\
\text { intestine }\end{array}$ & + & ++ & ++ & ++ & \pm+ & \pm+ & ++ & ++ & ++ & \pm \pm & \pm \pm \\
\hline
\end{tabular}

Mice were infected i.n. with $2.10^{5}$ PFU of MHV-76 per mouse. Titre of virus evaluated as(-) negative, $(+)$ positive specimens only in concentrated suspension, $(++)$ positive specimens in dilution $10^{-1},(+++)$ positive specimens in dilution $10^{-2} \cdot( \pm \pm) /( \pm \pm \pm)$ positivity of speciment confirmed with immunofluorescent method -IF

the highest virus titre from all investigated organs was observed in the lungs, but in comparison with the prototype strain MHV-68, the titre of virus was very low. Also in other organs titres of virus were significantly decreased. The character of chronic infection of MHV-76 (Table 2) was obviously different from the prototype strain infection as well as other MHV isolates. Establishment of latency was attenuated and virus persisted in most organs, especially in the liver, small intestine, spleen and kidneys. Surprisingly, we also detected MHV-76 in the brain.

Table 3a. Effect of MHV-76 infection on the number of leukocytes and on the presence of atypical lymphocytes of BALB/c mice in acute infection

\begin{tabular}{|l|c|c|c|c|c|c|c|c|c|}
\hline & 3 dpi & 5 dpi & 7 dpi & 12 dpi & 14 dpi & 20 dpi & 25 dpi & 28 dpi & Control \\
\hline $\begin{array}{l}\text { Number of } \\
\text { leukocytes/ } \\
1 \mu \text { blood }\end{array}$ & 11100 & 11820 & 6300 & 18900 & 8260 & 8500 & 1000 & 13600 & 8000 \\
\hline $\begin{array}{l}\% \text { of atypical } \\
\text { lymphocytes }\end{array}$ & $3 \%$ & $9.6 \%$ & $8.8 \%$ & $5 \%$ & $6.1 \%$ & $4 \%$ & $4.2 \%$ & $3.5 \%$ & $0 \%$ \\
\hline
\end{tabular}

Atypical leukocytes observed in MHV-76 acute infected mice are similar to atypical lymphocytes in EBV infected human blood in course IM.

In the second part of our study the analysis of differential white blood cell count of healthy/control and virus-infected BALB/c mice was followed (Tables 3a, 3b). The obtained results showed that the infection with MHV-76 was not accompanied with changes in the number of leukocytes and quality of differential white blood cell count in correlation with the duration of infection. During acute infection the frequency of atypical leukocytes was very low, reaching a maximum of $9.6 \%$ on day 5 p.i. In comparison with the control group, mice infected with MHV-76 had a slightly increased number of leukocytes with the highest numbers on day 12 p.i. $18900 \mathrm{leu} / \mu \mathrm{l}$ blood. During the acute and chronic phases of infection we did not observe significant splenomegaly. We investigated blood serum for MHV-76 
Table 3b. Effect of MHV-76 infection on the number of leukocytes and on the presence of atypical lymphocytes of BALB/c mice in chronic infection

\begin{tabular}{|l|c|c|c|c|c|c|c|c|c|c|c|}
\hline & $1 \mathrm{mpi}$ & $3 \mathrm{mpi}$ & $5 \mathrm{mpi}$ & $7 \mathrm{mpi}$ & $9 \mathrm{mpi}$ & $11 \mathrm{mpi}$ & $13 \mathrm{mpi}$ & $15 \mathrm{mpi}$ & $17 \mathrm{mpi}$ & $24 \mathrm{mpi}$ & $27 \mathrm{mpi}$ \\
\hline $\begin{array}{l}\text { Number of } \\
\text { leukocytes/ } \\
1 \mu \mathrm{l} \text { blood }\end{array}$ & 9200 & 11800 & 18600 & 10300 & 8100 & 11000 & 11300 & 16000 & 12900 & 9100 & 11200 \\
\hline $\begin{array}{l}\text { \% of atypical } \\
\text { lymphocytes }\end{array}$ & $6 \%$ & $3.8 \%$ & $9 \%$ & $13 \%$ & $3.5 \%$ & $10.5 \%$ & $14 \%$ & $15 \%$ & $8 \%$ & $13 \%$ & $8 \%$ \\
\hline
\end{tabular}

Atypical leukocytes observed in MHV-76 chronic infected mice could be classified as lymphoblasts (developing stages during maturation of neutrophile polymorphonuclear leukocytes)

antibodies and the maximum titre in virus neutralisation assay (titre 64) was found in the $10^{\text {th }}$ month p.i. During 27 months of MHV-76 infection, BALB/c mice did not develop tumours. Connection between infection and tumour development was not confirmed.

\section{Discussion}

During the acute phase of infection we found MHV-76 and its antigen in many organs: the blood, thymus, lungs, heart, liver, spleen, bone marrow, peritoneal macrophages, lymph nodes, kidneys, brain and small intestine, but on a very low level in comparison with the prototype strain and other MHV isolates (Mistríková et al. 1994, 2002; MrmusováŠupolíková et al. 2003; Pappová et al. 2004). The primary site of viral multiplication were the lungs with the virus spreading to other organs of the lymphatic system by haematogenous route. The MHV-76 strain was eliminated from lungs already on days 5 - 7 p.i. similarly as described by Macrae (2001), but on day 10 p.i. the BALB/c mice infected with MHV-76 did not show apparent symptoms of illness in the course of acute infection, while $48 \%$ of 6-week-old mice infected with the prototype strain MHV-68 developed clinical signs and symptoms of illness at that time (Sunil-Chandra et al. 1992). We detected the highest infectious titre of MHV-76 during acute infection between days 5 and 7 p.i. in lungs in comparison with other MHV-isolates, reaching the highest titre in lungs on days 10 - 14 28. p.i. (Mistríková et al. 1994, 2002; Mrmusová-Šupolíková et al. 2003; Pappová et al. 2004). Intranasal inoculation with MHV-76 also lead to an initial lung infection, but in comparison with other MHV-isolates, the virus titre was decreased. We detected a very low level of virus in other organs, too. The titre of virus neutralising antibodies was low, although the MHV antigen as well as the infectious virus was detected at chronic intervals (ranging from 2 to 27 months) in all tested organs. Surprisingly, MHV-76 was found in the liver, brain and intestinal wall, later it was especially increased at 27 months p.i. In comparison with the prototype strain, lymphocytosis was very low and splenomegaly was not observed at all. Significantly reduced splenomegaly after MHV-76 infection was also described by Macrae et al. 2001. This time it was accompanied with a mild increase of leukocytes and very low percentage of atypical lymphocytes. We detected the virus in mammary glands during chronic infection with the maximal titre on 11 and 13 months p.i. These findings also indicate the possibility of secretion of the virus by maternal milk similarly to EBV (Junker et al. 1991). EBV-induced infectious mononucleosis (IM) is a benign self-limited lymphoproliferative disease characterised by expansion of lymphoid cells into atypical lymphocytes (Tomkinson et al. 1987). We observed the presence of atypical lymphocytes (leukocytes) in the blood first in immunocompetent mice infected with MHV-72 (Mistríková and Mrmusová 1998) and later in T-cell-deficient nude mice (Rašlová et al. 2000). Atypical leukocytes observed in the MHV-72 infected mice could be classified as lymphoblasts (developing stages during maturation of neutrophil polymorphonuclear leukocytes) similarly as in patients with myeloid leukaemia. Also 
these atypical mouse leukocytes were highly similar in shape to those observed in patients suffering from infectious mononucleosis (Mistríková and Mrmusová 1998). In comparison with all MHV-isolates, MHV-76 caused very low levels of atypical leukocytes like IM or like the leukaemia syndrome (Mistríková et al. 2004). Persistence of the virus in many organs confirms the affinity of MHV-76 not only to cells of the lymphatic system, but also to neural cells (brain) and to glandular cells (mammary glands). Clambey et al. (2002) demonstrated that M1, M2, M3 and M4 genes and viral t-RNA-like genes are not essential for latency. A virus lacking these genes exhibits tissue-specific and route-ofinfection dependent alterations in latency and reactivation. In the chronic phase BALB/c mice developed tumours after MHV-78 (7\%), MHV-68 (11\%), MHV-72 (13\%), MHVŠumava (14.6\%) infection. In comparison with oncogenic MHV-strains, the chronic phase of infection with deletion mutant was not connected with tumour development. The presented results proved that MHV-76 is a lymphotropic virus, which has deletion of genes important in pathogenesis, namely in latency. And since the establishment of latency is needed for transformation with gammaherpesviruses, MHV-76 is a very important model for the study of latency and oncogenesis. During 27 months of infection with MHV-76 BALB/c mice did not develop tumours or the leukaemia-like syndrome. This is in contrast with MHV isolates, where latency was associated with lymphoproliferative disorders, lymphomas and even sarcomas in frequency of 7 to $22 \%$. Works of Townsley et al. (2004), Evans et al. (2006) and Geere et al. (2006) were concerned with the role of the M4 gene, but none of these publications studied the effect of the M4 gene on long-term infection or its relation to tumour development. We hypothesize that the M4 gene, presented in all MHV-oncogenic isolates, may be related (directly or indirectly) to their transforming properties.

\section{Patogenetická charakterizácia prirodzeného 9.5-kilobázového delečného mutanta (MHV-76) lymfotropného myšacieho gamaherpesvírusu 68}

Myšací gamaherpesvírus 4 (MuHV-4) predstavuje zvierací model na štúdium živočíšnych gamaherpesvírusov. MHV-76 je prirodzeným delečným mutantom prototypového kmeňa MuHV-4 (MHV-68). MHV-76 chýba aspoň 12 otvorených čítacích rámcov na 5' konci vrátane génov M1, M2, M3, M4 a osem vírusom kódovaných tRNApodobných génov. 27 mesačná experimentálna infekcia BALB/c myší bola sledovaná po patogenetickej, imunologickej a onkogenetickej stránke. Po intranazálnej infekcii s MHV-76 bol infekčný vírus detegovaný v krvi, týmuse, pl'úcach, srdci, pečeni, slezine, kostnej dreni, peritoneálnych makrofágoch, lymfatických uzlinách, obličkách, mliečnych žl’azách, mozgu a tenkom čreve. Akútna fáza infekcie bola atenuovaná, ale chronická infekcia bola sprevádzaná dlhotrvajúcou perzistenciou vírusu nielen v lymfatických, ale aj v nervových a glandulárnych tkanivách. Pri porovnaní s prototypovým kmeňom bola splenomegália a lymfocytóza vel'mi mierna. Počas 27-mesačnej infekcie BALB/c myší s MHV-76 sa prekvapivo neobjavilo lymfoproliferatívne ochorenie podobné infekčnej mononukleóze, leukémia ani lymfómy. Predpokladáme, že M4 gén, vyskytujúci sa u všetkých onkogénnych MHV izolátov, by mohol byt’ zapojený (priamo alebo nepriamo) do ich transformujúcich vlastností.

\section{Acknowledgement}

This work has been supported by the grant No 1/0083/08 of the Scientific Grant Agency of the Ministry of Education of the Slovak Republic and the Slovak Academy of Sciences and by the Slovak Research and Development Agency under the contact No. APVV-51-005-005

\section{References}

BLAŠKOVIČ D, STANČEKOVÁ M, SVOBODOVÁ J, MISTRÍKOVÁ J 1980: Isolation of five strains of herpesviruses from two species of free living small rodents. Acta Virol 24: 468 
CLAMBEY ET, VIRGIN HWI, SPECK SH 2002: Characterisation of a spontaneous 9.5-kilobase-deletion mutant of murine gammaherpesvirus 68 reveals tissue-specific genetic requirements for latency. J Virol 76: 6532-6544

EFSTATHIOU S, HO YM, MINSON AC 1990: Cloning and molecular characterization of the murine herpesvirus 68 genome. J Gen Virol 71:1355-1364

EVANS AG, MOORMAN NJ, WILLER DO, SPECK SH 2006: The M4 gene of $\gamma H V 68$ encodes a secreted glycoprotein and is required for the efficient establishment of splenic latency. Virology 344: 520-531

FAUQUET CM, MAYO MA, MANILOFF J, DESSELBERGER U, BALL LA (Eds.) 2005: Virus Taxonomy. Eighth Report of the International Committee on Taxonomy of Viruses. Elsevier-Academic Press, London, $1162 \mathrm{p}$.

GEERE HM, LIGERTWOOD Y, TEMPLETON KM, BENNET I, GANGADHARAN B, RHIND SM, NASH AA, DUTIA BM 2006: The M4 gene of murine gammaherpesvirus 68 modulates latent infection. J Gen Virol 87: $803-807$

HAMELIN C, LUSSIER G 1992: Characterization of DNA of rodent herpesviruses by restriction endonuclease analysis and hybridization. Lab Anim Sci 42: 142-5

JUNKER AK, THOMAS EE, RADCLIFFE A, FORSYTH RB, DAVIDSON AG, RYMO L 1991: Epstein-Barr virus shedding in breast milk. Am J Med Sci 302: 220-223

MACRAE AI, DUTIA BM, MILLIGAN S, BROWNSTEIN DG, ALLEN DJ, MISTRÍKOVÁ J, DAVISON AJ, NASH AA, STEWART JP 2001: Analysis of novel strain of murine gammaherpesvirus reveals a genomic locus important for acute pathogenesis. J Virol 75: 5315-5327

MATUŠKOVÁ M, MISTRIKOVÁ J, MRMUSOVÁ M, ŽILKA N, STANČEKOVÁ M, KONTSEKOVÁ E 2003: Antigenic relationship between five isolates of murine gammaherpesvirus analysed with monoclonal antibodies. Arch Virol 148: 1027-1036

MISTRÍKOVÁ J, REMEŇOVÁ A, LEŠŠO J, STANČEKOVÁ M 1994: Replication and persistence of murine herpesvirus 72 in lymphatic system and peripheral blood mononuclear cells of BALB/c mice. Acta Virol 38: $151-156$

MISTRÍKOVÁ J, RAJČÁNI J, MRMUSOVÁ M, ORAVCOVÁ I 1996: Chronic infection of BALB/c mice with murine herpesvirus 72 associated with neoplasm development. Acta Virol 40: 297-301

MISTRÍKOVÁ J, MRMUSOVÁ M 1998: Detection of abnormal lymphocytes in the blood of BALB/c mice infected with murine gammaherpesvirus strain 72: the analogy with Epstein-Barr virus infection. Acta Virol 42:79-82

MISTRÍKOVÁ J, MOŠKO T, MRMUSOVÁ M 2002: Pathogenic characterization of a mouse herpesvirus isolate Šumava. Acta Virol 46: 41-46

MISTRÍKOVÁ J, MRMUSOVÁ-ŠUPOLÍKOVÁ M, RAJČÁNI J 2004: Leukemia-like syndrome in BALB/c mice infected with the lymphotropic gammaherpesvirus MHV-Šmava: an analogy to EBV infection. Neoplasma 51: 71-76

MRMUSOVÁ-ŠUPOLÍKOVÁ M, PAPPOVÁ M, MISTRÍKOVÁ J 2003: Pathogenesis of murine lymphotropic gammaherpesvirus isolate 78. Acta Vet Brno 72: 371-376

PAPPOVÁ M, STANČEKOVÁ M, SPIŠŠÁKOVÁ I, ĎURMANOVÁ, V MISTRÍKOVÁ J 2004: Pathogenetical characterization of isolate MHV-60 of mouse herpesvirus strain 68. Acta Virol 48: 91-96

RAŠLOVÁ H, MISTRÍKOVÁ J, KÚDELOVÁ M, MISHAL Z, SARASIN A, BLANGY D, BEREBBI M 2000 : Immunophenotypic study of atypical lymphocytes generated in peripheral blood and spleen of nude mice after MHV-72 infection. Viral Immunol 13: 313-327

REICHEL M, MATIS J, LEŠŠO J, STANČEKOVÁ M 1991: Polypeptides synthesized in rabbit cells infected with murine herpesvirus (MHV): a comparison of proteins specified by various MHV strains. Acta Virol 35: 268-275

SVOBODOVÁ J, BLAŠKOVIČ D, MISTRÍKOVÁ J 1982: Growth characteristic of herpesviruses isolated from two species of free living small rodents. Acta Virol 26: 256-263

SUNIL-CHANDRA NP, EFSTATHIOU S, ARNO J, NASH AA 1992: Virological and pathological features of mice infected with murine gamma-herpesvirus 68. J Gen Virol 73: 2347-2356

SUNIL-CHANDRA NP, ARNO J, FAZAKERLEY J, NASH AA 1994: Lymphoproliferative disease in mice infected with murine gammaherpesvirus 68. Am J Pathol 145: 818-826

TOMKINSON BE, WAGNER DK, NELSON DL, SULLIVAN JL 1987: Activated lymhocytes during acute Epstein-Barr virus infection. J Immunol 139: 3802-3807

TOWNSLEY AC, DUTIA BM, NASHAA 2004: The M4 gene of murine gammaherpesvirus modulates productive and latent infection in vivo. J Virol 78: 758-767 
